\title{
Review \\ Can Endometriosis-Related Oxidative Stress Pave the Way for New Treatment Targets?
}

\author{
Luciana Cacciottola $^{1}$, Jacques Donnez ${ }^{2,3}$ and Marie-Madeleine Dolmans ${ }^{1,4, *}$ \\ 1 Gynecology Research Unit, Institut de Recherche Expérimentale et Clinique, Université Catholique de \\ Louvain, 1200 Brussels, Belgium; luciana.cacciottola@uclouvain.be \\ 2 Society for Research into Infertility, 1150 Brussels, Belgium; jacques.donnez@gmail.com \\ 3 Université Catholique de Louvain, 1200 Brussels, Belgium \\ 4 Department of Gynecology, Cliniques Universitaires Saint-Luc, 1200 Brussels, Belgium \\ * Correspondence: marie-madeleine.dolmans@uclouvain.be; Tel.: +32-(0)2-764-5287
}

check for updates

Citation: Cacciottola, L.; Donnez, J.; Dolmans, M.-M. Can

Endometriosis-Related Oxidative Stress Pave the Way for New Treatment Targets? Int. J. Mol. Sci. 2021, 22, 7138. https://doi.org/ $10.3390 /$ ijms 22137138

Academic Editor: Jerome F. Strauss III

Received: 1 June 2021

Accepted: 28 June 2021

Published: 1 July 2021

Publisher's Note: MDPI stays neutral with regard to jurisdictional claims in published maps and institutional affiliations.

Copyright: (c) 2021 by the authors. Licensee MDPI, Basel, Switzerland. This article is an open access article distributed under the terms and conditions of the Creative Commons Attribution (CC BY) license (https:/ / creativecommons.org/licenses/by/ $4.0 /)$.

\begin{abstract}
Endometriosis is a disease of reproductive age characterized by chronic pelvic pain and infertility. Its pathogenesis is complex and still partially unexplained. However, there is increasing evidence of the role of chronic inflammation, immune system dysregulation, and oxidative stress in its development and progression. The latter appears to be involved in multiple aspects of the disease. Indeed, disease progression sustained by a hyperproliferative phenotype can be related to reactive oxygen species (ROS) imbalance, as numerous experiments using drugs to counteract hyperproliferation have shown in recent years. Chronic pelvic pain is also associated with cell function dysregulation favoring chronic inflammation and oxidative stress, specifically involving macrophages and mast cell activation. Moreover, there is increasing evidence of a role for ROS and impaired mitochondrial function not only as deleterious effectors of the ovarian reserve in patients with endometriomas but also in terms of oocyte quality and, hence, embryo development impairment. Targeting oxidative stress looks to be a promising strategy to both curb endometriotic lesion progression and alleviate endometriosis-associated symptoms of chronic pain and infertility. More investigations are nevertheless needed to develop effective therapeutic strategies for clinical application.
\end{abstract}

Keywords: endometriosis; oxidative stress; iron overload; antioxidants; macrophages; hyperalgesia; chronic pain; infertility

\section{Introduction}

Endometriosis is a chronic disease characterized by implantation and growth of endometrial-like tissue, including glands and stroma, outside the uterine cavity [1,2]. It affects about $10 \%$ of women of childbearing age and is associated with debilitating chronic pelvic pain and infertility [3,4], causing significant impairment to quality of life and inevitably impacting social, occupational, and psychological aspects, too [5].

Although the pathophysiology of endometriosis remains poorly understood, various biological processes are known to be key players in its development and progression. Ectopic endometrium is able to survive outside the uterus and adhere to the peritoneum by activation of adhesion molecules and their receptors [6,7] and overexpression of matrix metalloproteinases [8] and plasminogen activators [9]. These implants acquire other crucial characteristics such as unrestrained growth through steroid receptivity dysregulation $[1,2,10,11]$, as well as proangiogenic features [12,13]. Moreover, the inflammatory response and immune system modulation promoting ectopic endometrium implantation initially, and implant maintenance and progression subsequently, also appears to be pivotal $[2,14]$. Oxidative stress, namely disequilibrium between production and neutralization of reactive oxygen species (ROS), has been shown to be present in these processes and looks to play a key role in disease pathogenesis and evolution [15-17]. 
As described by Nisolle and Donnez [18], there are three forms of the disease, as endometriotic lesions can develop (i) on the peritoneum as superficial disease, (ii) inside the ovaries as cysts, and (iii) as deep-infiltrating disease most commonly observed in the rectovaginal septum. Endometriosis staging is based on the anatomic location and severity of the disease according to the American Society for Reproductive Medicine (ASRM) classification [19]. While this classification has a somewhat weak correlation with pain and infertility symptoms, it does allow the comparison of surgical findings and outcomes of different treatments. Current treatment options include surgical ablation or excision of lesions in the pelvic cavity or hormone therapy to suppress lesion proliferation [1]. The latter is effective for pain and reducing the risk of recurrence after surgery but is not indicated for infertility-associated endometriosis, as hormones block ovarian function [20]. Endometriosis-related infertility can be addressed by surgery to increase the chances of pregnancy in specific cases. Furthermore, assisted reproductive technology (ART) should be offered to infertile endometriosis patients who are unsuitable candidates for natural conception [20]. Previous surgery, advanced disease stage, and association with adenomyosis and ovarian and/or deep nodular endometriosis appear to be linked to poorer ART outcomes [21,22], but in vitro fertilization (IVF) is still the most effective strategy to manage infertility in these patients [20-23].

There is a clear clinical need for new therapeutic approaches, not only to treat endometriosis-related symptoms such as chronic pain and infertility but also to curtail its recurrence and progression. Oxidative stress may be a potential therapeutic target for both objectives, as it plays a crucial role in disease development and evolution.

\section{ROS and Antioxidant Defense}

The clinical importance of oxygen toxicity was not fully appreciated until an epidemic of retrolental fibroplasia (severe retinopathy) occurred in the early 1950s [24]. Indeed, oxygen at high partial pressures is toxic to the respiratory, cardiovascular, nervous, and gastrointestinal systems. Toxicity results from the formation of ROS, which are chemically reactive molecules produced naturally within biological systems.

ROS are actually intermediaries produced by normal oxygen metabolism but are known to have deleterious effects. To protect themselves, cells have developed a wide range of antioxidant systems to limit the production of ROS, inactivate them, and repair cell damage $[16,17,25-28]$. In healthy individuals, ROS and antioxidants are balanced, but when the balance is tipped toward an overabundance of ROS, oxidative stress is triggered and can impact the entire reproductive lifespan of a woman, as reported by Ruder et al. [25].

It is clear that ROS are generated within cells in the course of normal cellular mechanisms and that cells are adequately equipped with a range of cytoprotective enzymes and antioxidants to combat their toxicity $[16,17,25,26,28]$. One of the master regulators of cytoprotective defense against oxidative stress is the nuclear factor erythroid 2-related factor 2/Kelch ECH associated protein 1 (Nrf2/KEP1) pathway [29]. Activation and translocation to the nucleus of Nrf2 initiates the transcription of a number of genes, known as antioxidant response elements, involved in redox homeostasis and protection from oxidative stress-related injury [30]. This response includes an increase in antioxidant systems such as superoxide dismutase (SOD) and catalase (CAT), elevated autophagic cell activity for repair of various cell compartments, and also mitochondrial biogenesis [29,30].

However, excessive release of ROS induces cellular damage and likely alters cellular function by regulating protein activity and gene expression. Indeed, ROS play an essential role in regulating the transcription factor nuclear factor kappa B (NFkB), which has been implicated in endometriosis [2,31]. This transcription factor triggers the expression of multiple genes encoding proinflammatory cytokines, growth and angiogenic factors, adhesion molecules, and inducible enzymes nitric oxide synthase (NOS) and cyclooxygenase (COX) $[32,33]$. All these constituents are expressed by activated peritoneal macrophages and are involved in the pathogenesis of endometriosis by inducing endometrial fragment adhesion, proliferation, and neovascularization [32,34]. 


\section{Origin of Oxidative Stress in the Peritoneal Cavity}

\subsection{Erythrocytes and Hemoglobin}

Understanding the role of hemoglobin $(\mathrm{Hb})$, heme, and the iron-induced redox balance in endometriosis has given rise to several hypotheses to explain why oxidative stress is triggered in the case of pelvic endometriosis [17] and is potentially involved in its pathophysiology. Erythrocytes, apoptotic endometrial tissue, and cell debris swept into the peritoneal cavity by menstrual reflux and macrophages have all been suggested as possible inducers of oxidative stress [16,35-40].

Erythrocytes are likely to release pro-oxidant and proinflammatory factors such as $\mathrm{Hb}$ and its highly toxic by-products heme and iron into the peritoneal environment. While iron and heme are fundamental to living cells, unless they are properly chelated, free iron and (to a lesser degree) heme play key roles in the formation of deleterious ROS [40-43].

However, erythrocytes are observed in the peritoneal cavity of $90 \%$ of menstruating women [18], so it is puzzling why some patients develop macroscopically visible peritoneal endometriotic lesions while others do not [44]. One theory is that peritoneal protective mechanisms may be swamped by menstrual reflux in some patients, either because of its abundance or due to defective scavenging systems [40-43] (Figure 1).

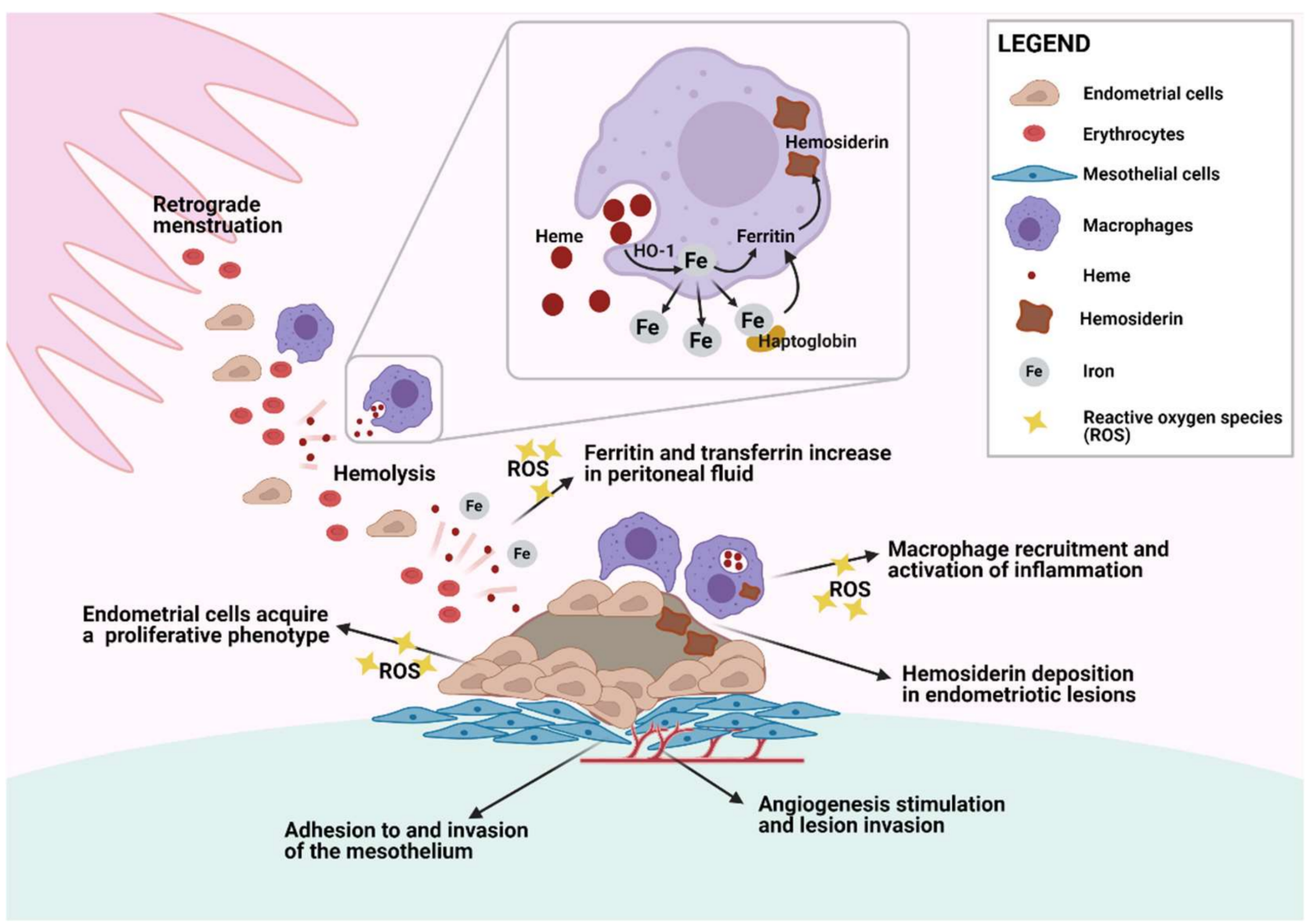

Figure 1. Endometrial cell and macrophage interaction in the pelvic cavity. Erythrocytes and endometrial cells are carried into the pelvic cavity by retrograde menstruation and are phagocytosed by peritoneal macrophages. Heme digestion by heme oxygenase 1 (HO-1) releases iron, which is either stored in the form of ferritin and hemosiderin or released to bind to transferrin. Endometrial cells with adhesive characteristics start to invade the mesothelium and trigger inflammatory signals that recruit more peritoneal macrophages. Local inflammation and increased levels of reactive oxygen species (ROS) contribute to the acquisition of a proliferative phenotype and proangiogenic features that are crucial to endometriotic lesion development. Created with biorender.com (accessed on 29 May 2021). 


\subsection{Iron Metabolism in the Pelvic Cavity}

In case of hemorrhage, lysis of erythrocytes results in iron overload, which in turn causes iron-mediated damage, oxidative injury, and inflammation [45-47], so iron may well be implicated in endometriosis development [28,43,45,47]. A crucial defense mechanism counteracting the effects of hemorrhage is mediated by haptoglobin (Hp), which binds to extracellular $\mathrm{Hb}$, thereby weakening its oxidative and inflammatory potential. Moreover, $\mathrm{Hp}$ promotes the clearance of $\mathrm{Hb}$ via the $\mathrm{CD} 163$ scavenger receptor present on macrophages [46].

As in most tissue, activated macrophages recruited inside the pelvic cavity of women play a vital role in the degradation of erythrocytes, as indicated by the presence of numerous iron-laden macrophages in the peritoneal fluid of endometriosis subjects $[33,34]$ and mice injected intraperitoneally with erythrocytes [40]. Macrophages generally phagocytose senescent erythrocytes or endocytose the $\mathrm{Hb}-\mathrm{Hp}$ complex [46]. Thus, $\mathrm{Hb}$ and heme metabolism by heme oxygenase $(\mathrm{HO})$ releases iron, which is then integrated into ferritin in macrophages or returned to the iron transporter transferrin via peritoneal fluid [48].

Iron conglomerates have also been encountered in endometriotic lesions [37,43], composed of hemosiderin, another iron storage form found in conditions of iron overload and usually associated with toxic pathological states in humans. Iron storage is significantly greater in peritoneal macrophages of endometriosis patients than in controls [43]. Cellular iron storage within ferritin limits the ability of iron to generate ROS, conferring an antioxidant effect [43]. However, continued delivery of iron to macrophages may overwhelm the capacity of ferritin to store and sequester the metal, causing oxidative damage to cells.

\subsection{Cellular Damage and Adhesion and Growth of Ectopic Endometrial Tissue}

In many other tissues, iron is known to induce oxidative stress, resulting in macromolecular oxidative damage, tissue injury, and chronic inflammation [39,47,49]. It was therefore suggested that oxidative stress could be responsible for local destruction of the peritoneal mesothelium, creating adhesion sites for ectopic endometrial cells $[16,33,50]$ and promoting invasion $[15,51,52]$.

\subsection{Heme Oxygenase-1 Detoxification System}

Heme oxygenase-1 (HO-1) is a heme-degrading enzyme strongly upregulated by heme that shields cells from heme-induced oxidative stress by generating beneficial molecules such as carbon monoxide (CO), bilirubin, and ferritin. Indeed, induction of HO-1 is accompanied by increased ferritin synthesis, scavenging of free iron, and, ultimately, protection against its adverse effects [53]. Bilirubin is an important antioxidant defending against oxidative damage and inflammation [54], while CO is a soluble gas acting as a signal molecule.

HO-1, which has a number of triggers such as ROS, free heme, heavy metals, and cytokines [28,55], is able to break down $\mathrm{Hb}$ and release iron from heme. Together with iron, $\mathrm{HO}-1$ boosts levels of $\mathrm{CO}$ and biliverdin, both of which play a unique protective and antioxidant role, as well as possessing anti-inflammatory and antiapoptotic properties. $\mathrm{HO}-1$-induced cytoprotective effects require co-expression of ferritin, but $\mathrm{CO}$ has been shown to exert significant cytoprotective, anti-inflammatory, and antiapoptotic properties all by itself $[28,36]$.

In endometriosis patients, $\mathrm{Hb}$ concentrations were found to be higher in peritoneal fluid, and stronger $\mathrm{HO}$ expression was observed in ectopic endometrium, particularly red lesions, compared to eutopic endometrium and mesothelial cells $[16,36]$. However, since inducible HO-1 was weakly expressed by macrophages and mesothelial cells that make up the majority of cells in the peritoneal cavity, and because there was no concomitant upturn in peritoneal fluid levels of its final by-product bilirubin, it strongly infers that detoxifying systems, while present, may be inadequate to metabolize $\mathrm{Hb}$ in the case of endometriosis $[37,43]$. 
In conclusion, oxidative stress arises when the balance between ROS production and antioxidant defense is disrupted $[16,26,35,52]$ due to either insufficient antioxidant protection or excess ROS production.

\section{ROS as Potential Therapeutic Targets for Endometriosis Progression}

\subsection{Proliferative Phenotype}

A proliferative phenotype of endometrial cells in patients affected by endometriosis compared with unaffected subjects has been identified, showing features that are commonly observed in cancer cells: uncontrolled growth, proangiogenic factors, and the ability to escape apoptosis [56]. A proliferative phenotype is sustained by dysregulation of estrogen and progesterone receptor expression in ectopic endometrium, leading to progesterone resistance and curtailing the capacity of progestins to control endometriosis progression [2,57]. Such hormonal dysregulation enhances the inflammatory environment through prostaglandin generation and contributes to pro-oxidant conditions in ectopic lesions [2]. For this reason, therapeutic strategies combining non-steroidal anti-inflammatory drugs with chronic hormone treatment, such as estroprogestins or progestins alone $[57,58]$, are effective in managing disease progression only in two-thirds of cases [57]. Selective progesterone receptor modulators (SPRMs), such as mifepristone, are also able to significantly reduce endometrial proliferation and, hence, the development of endometriotic lesions [59]. However, their pharmacological safety profile, showing increased toxicity and risk of hepatic dysfunction with chronic use, has limited their application in clinical settings and further research into their suitability [59].

Increased ROS levels in endometriosis are not only a consequence of chronic inflammation that characterizes this disease but are also caused by ROS detoxification pathway dysregulation [60]. Both an upturn in hydrogen peroxide production by mitochondrial superoxide dismutase activity and a drop in catalase activity were found to elevate ROS levels in endometriotic lesions [60]. ROS may therefore play a role as signaling molecules to sustain an endometriosis-associated proliferative phenotype. Indeed, they are known to exert influence as second messengers for cell proliferation by activating growth-related signaling pathways such as serine/threonine-protein kinase/mitogen-activated kinase/extracellular signal-regulated kinase (Raf/MEK/ERK), which is involved in proliferation in response to higher endogenous ROS levels [61] (Figure 2). ERK 1 and 2, members of the MAPK family, reside in the cytoplasm and undergo nuclear translocation when triggered by MEK 1 and 2 to promote gene expression for cellular proliferation, survival, differentiation, and adhesion. This pathway was found to be upregulated in both eutopic and ectopic endometrial cells of subjects with endometriosis [62], and its upregulation was related to increased ROS values [60], as also observed in cancer cells [61]. This was evidenced in both ectopic and eutopic endometrial cells, suggesting the presence of pre-existing alterations to redox balance and the Raf/MEK/ERK pathway in favor of proliferative cell phenotypes for migration and implantation of ectopic endometriotic tissue [63,64]. Downregulation of ERK1/2 activation through first-generation MEK-1/2 inhibitors demonstrated a decrease in human endometrial cell proliferation in vitro and in human endometriotic lesions grafted to nude mice [64]. Other drugs suppressing the same pathway were also tested on murine models of endometriosis (Table 1). 


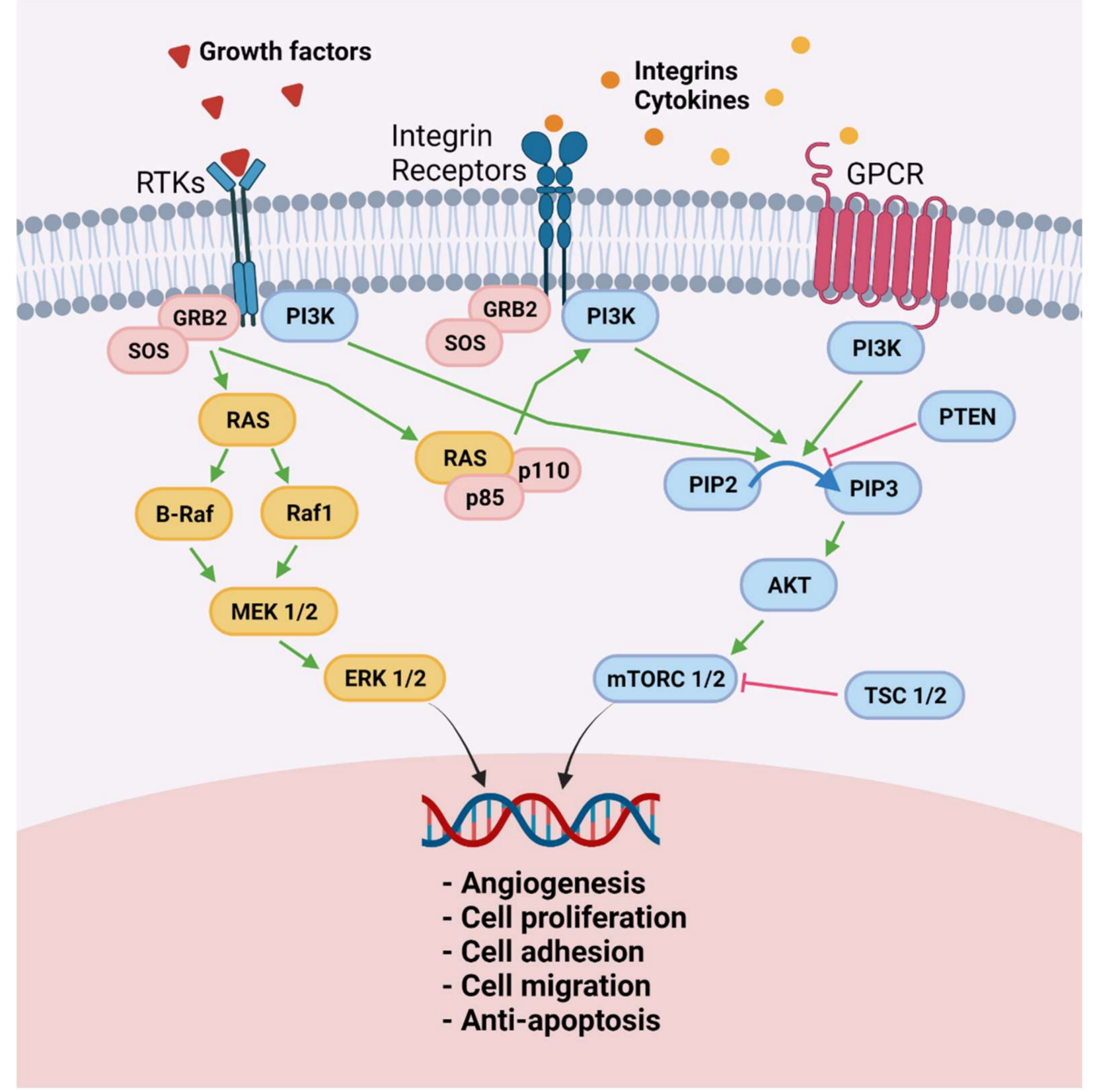

Figure 2. Raf/MEK/ERK and PI3K/Akt/mTOR pathways in ectopic endometrial cells. Molecule-like growth factors, integrins, and cytokines that bind to receptors on the cell surface activate both the Raf/MEK/ERK and the PI3k/Akt/mTOR signaling pathways in endometrial cells to acquire proangiogenic features, proliferation ability, increased adhesion and migration capacity, and resistance to apoptosis: RTKs, receptor tyrosine kinases; GRB2, growth factor receptor-bound protein 2; SOS, son of sevenless; Raf, serine/threonine-protein kinase; MEK $\frac{1}{2}$, mitogen-activated protein kinase; ERK $\frac{1}{2}$, extracellular signal-regulated kinase; GPCR, G protein-coupled receptor; PI3K, phosphoinositide 3 kinase; PTEN, phosphatase and tensin homolog; p110; p85 PIP2, phosphatidylinositol 4,5-bisphosphate; PIP3, phosphatidylinositol 3,4,5-trisphosphate; Akt, protein kinase B; mTORC1, mammalian target of rapamycin complex 1 ; TSC $\frac{1}{2}$, tuberous sclerosis complex 2 . Created with biorender.com (accessed on 28 May 2021). 
Table 1. Drugs antagonizing the hyperproliferative phenotype.

\begin{tabular}{|c|c|c|c|c|}
\hline Reference & Drug & Effect & Endometriosis Source & Experimental Model \\
\hline $\begin{array}{l}\text { Leconte et al., } \\
2010[65]\end{array}$ & $\begin{array}{l}\text { Cannabinoid } \\
\text { agonists }\end{array}$ & $\begin{array}{c}\text { Inhibition of } \\
\text { PI3K/Akt/mTOR pathway } \\
\text { Drop in cell proliferation } \\
\text { Reduced ROS generation } \\
\text { Lower NO levels } \\
\text { Decline in endometriotic lesion volume }\end{array}$ & Human (DIE) & $\begin{array}{l}\text { In vitro culture; } \\
\text { xenotransplantation murine model }\end{array}$ \\
\hline $\begin{array}{l}\text { Zhang et al., } \\
2011[66]\end{array}$ & Curcumin & $\begin{array}{l}\text { Decline in endometriotic lesion volume } \\
\text { Lower VEGF levels } \\
\text { Lower microvessel density }\end{array}$ & Rodent (rat) & Autotransplantation rat model \\
\hline $\begin{array}{l}\text { Jana et al., } \\
2012 \text { [67] }\end{array}$ & Curcumin & $\begin{array}{c}\text { Increase in apoptosis rates } \\
\text { Higher MMP-3 levels }\end{array}$ & Rodent (mouse) & Autotransplantation murine model \\
\hline $\begin{array}{l}\text { Defrère et al., } \\
2006 \text { [40] }\end{array}$ & Desferrioxamine & $\begin{array}{l}\text { Drop in cell proliferation } \\
\text { lower iron levels in lesions, } \\
\text { macrophages, and peritoneal fluid }\end{array}$ & $\begin{array}{l}\text { Human (menstrual } \\
\text { endometrium) }\end{array}$ & Xenotransplantation murine model \\
\hline $\begin{array}{l}\text { Li et al., } 2020 \\
{[68]}\end{array}$ & $\begin{array}{l}\text { Erastin } \\
\text { ERK inhibitors }\end{array}$ & $\begin{array}{l}\text { Increase in total and lipid ROS values } \\
\text { Upturn in iron levels } \\
\text { Decline in endometriotic lesion volume } \\
\text { Inhibition of Raf/MEK/ERK pathway }\end{array}$ & $\begin{array}{c}\text { Human } \\
\text { (endometriomas) }\end{array}$ & Xenotransplantation murine model \\
\hline $\begin{array}{l}\text { Leconte et al., } \\
\quad 2011[69]\end{array}$ & Temsirolimus & $\begin{array}{l}\text { Drop in cell proliferation } \\
\text { Inhibition of } \\
\text { PI3K/Akt/mTOR pathway } \\
\text { Drop in cell proliferation } \\
\text { Reduced ROS generation }\end{array}$ & Human (DIE) & $\begin{array}{l}\text { In vitro culture; } \\
\text { xenotransplantation murine model }\end{array}$ \\
\hline $\begin{array}{l}\text { Ngo et al., } \\
2010 \text { [64] }\end{array}$ & $\begin{array}{l}\text { Leflunomide, MEK } \\
1 / 2 \text { inhibitors }\end{array}$ & $\begin{array}{l}\text { Inhibition of Raf/MEK/ERK pathway } \\
\text { Drop in cell proliferation } \\
\text { Decline in endometriotic lesion volume }\end{array}$ & $\begin{array}{l}\text { Human (endometriomas } \\
\text { and DIE) }\end{array}$ & $\begin{array}{l}\text { In vitro culture; } \\
\text { xenotransplantation murine model }\end{array}$ \\
\hline $\begin{array}{l}\text { Park et al., } \\
2017[70]\end{array}$ & Naringenin & $\begin{array}{c}\text { Drop in cell proliferation } \\
\text { Inhibition of } \\
\text { PI3K/Akt/mTOR pathway } \\
\text { Increased levels of ER stress and ROS }\end{array}$ & $\begin{array}{l}\text { Human (pelvic } \\
\text { endometriotic lesions) }\end{array}$ & In vitro culture \\
\hline $\begin{array}{l}\text { Kapoor et al., } \\
2018 \text { [71] }\end{array}$ & Naringenin & $\begin{array}{l}\text { Decline in endometriotic lesion volume } \\
\text { Lower TNF } \alpha \text { and NO levels } \\
\text { Inhibition of Nrf2/KEAP1 pathway } \\
\text { Increase in mitochondrial damage, } \\
\text { ROS, and apoptosis }\end{array}$ & Rodent (rat) & $\begin{array}{l}\text { In vitro culture; } \\
\text { autotransplantation rat model }\end{array}$ \\
\hline $\begin{array}{l}\text { Pittalunga } \\
\text { et al., 2010 } \\
\text { [72] }\end{array}$ & NAC & $\begin{array}{l}\text { Decline in endometriotic lesion volume } \\
\text { Decrease in COX-2 and } \\
\text { MMP-9 expression }\end{array}$ & Rodent (mouse) & Allotransplantation murine model \\
\hline $\begin{array}{l}\text { Porpora et al., } \\
2013 \text { [73] }\end{array}$ & NAC & $\begin{array}{c}\text { Decline in endometriotic lesion volume } \\
\text { Decrease in COX-2 expression } \\
\text { Alleviation of } \\
\text { endometriosis-related pain }\end{array}$ & $\begin{array}{l}\text { Human (endometriomas } \\
\qquad>3 \mathrm{~cm} \text { ) }\end{array}$ & $\begin{array}{l}\text { Endometriosis patients with } \\
\text { chronic pain and infertility }\end{array}$ \\
\hline $\begin{array}{l}\text { Rudzitis- } \\
\text { Auth et al., } \\
2013 \text { [74] }\end{array}$ & Resveratrol & $\begin{array}{l}\text { Drop in cell proliferation } \\
\text { Decline in endometriotic lesion volume } \\
\text { Lower microvessel density }\end{array}$ & Rodent (mouse) & Allotransplantation murine model \\
\hline $\begin{array}{l}\text { Taguchi et al., } \\
2014 \text { [75] }\end{array}$ & Resveratrol & $\begin{array}{l}\text { No difference in cell proliferation } \\
\text { Decrease in IL-8 expression }\end{array}$ & $\begin{array}{l}\text { Human } \\
\text { (endometriomas) }\end{array}$ & In vitro culture \\
\hline $\begin{array}{l}\text { Ozer et al., } \\
2013 \text { [76] }\end{array}$ & Sorafenib & $\begin{array}{l}\text { No difference in implant volume } \\
\text { Lower microvessel density }\end{array}$ & Rodent (rat) & Autotransplantation rat model \\
\hline $\begin{array}{l}\text { Yildiz et al., } \\
2015 \text { [77] }\end{array}$ & Sorafenib & $\begin{array}{l}\text { No difference in proliferation rates } \\
\text { No difference in apoptosis rates } \\
\text { Decrease in VEGF expression }\end{array}$ & Rodent (rat) & Autotransplantation rat model \\
\hline $\begin{array}{l}\text { Leconte et al., } \\
\quad 2015[78]\end{array}$ & Sorafenib & $\begin{array}{l}\text { Inhibition of Raf/MEK/ERK pathway } \\
\text { Drop in cell proliferation }\end{array}$ & $\begin{array}{l}\text { Human (endometriomas } \\
\text { and DIE) }\end{array}$ & $\begin{array}{l}\text { In vitro culture; } \\
\text { xenotransplantation murine model }\end{array}$ \\
\hline
\end{tabular}

ERK, extracellular signal-regulated kinase; NAC, N-acetylcysteine; MEK, mitogen-activated protein kinase; PI3K/Akt/mTOR, phosphoinositol 3-kinase/protein kinase B/mammalian target of rapamycin; ROS, reactive oxygen species; Raf, serine/threonine-protein kinase; NO, nitric oxide; VEGF, vascular endotheliam growth factor; MMP-3/9, matrix metralloproteinase 3/9; TNF- $\alpha$, tumor necrosis factor $\alpha$; Nrf2/KEAP1, nuclear factor erythroid 2-related factor 2/Kelch ECH associated protein 1; ER, endoplasmic reticulum; COX-2, cyclooxygenase 2; IL-8, interleukin 8; DIE, deep-infiltrating endometriosis.

Leflunomide, acting as a tyrosine kinase inhibitor to suppress NFkB transcription [79], was shown to decrease proliferative activity in ectopic endometrial cells [64,80]. Sorafenib, a multikinase inhibitor targeting the serine/threonine RAF kinases (RAF-1 and B-RAF) and vascular endothelial growth factors (VEGF) receptors with antiproliferative effects in cancer [81], was found to reduce the proliferation of human stromal cells in deep endometriotic nodules, as well as in vivo proliferation in induced murine models (with the same 
deep nodular endometriosis), by suppressing ERK phosphorylation and VEGF receptor 2 activity [78]. However, the use of sorafenib was shown to yield conflicting results in terms of antiproliferative and antiangiogenic properties in rat models of endometriosis [76,77]. This disparity in effectiveness may be due not only to bias from the use of animal models for endometriosis but also from variations in stromal and endometrial cell regulators in endometriotic lesions. Indeed, ectopic stromal cell proliferation was found to be less related to ROS-dependent ERK1/2 upregulation, as in the case of endometriomas, suggesting other mechanisms maintaining cells in a hyperproliferative state [69]. Among them, the phosphoinositol 3-kinase/protein kinase B/mammalian target of rapamycin (PI3K/Akt/mTOR) pathway, known to regulate numerous cell functions such as metabolism, growth, and survival, may play a key role since it was shown to be activated in both ovarian and deep nodular endometriosis [82] (Figure 2).

Cannabinoid agonists have antiproliferative properties inhibiting both the Raf/MEK/ ERK and the PI3K/Akt/mTOR pathways and have proved effective in suppressing proliferation in deep nodular endometriosis [65], confirming the hypothesis of multiple proliferative pathways responsible for endometriotic lesion progression. Moreover, the drop in proliferation rate in cells isolated from deep-infiltrating endometriotic lesions after treatment with temsirolimus, an inhibitor of the PI3K/Akt pathway through its effector mTOR, evidenced the specific link between activation of this signaling pathway and the hyperproliferative phenotype of deep nodular endometriosis [69].

Although efforts made to elucidate the role of a proliferative phenotype in endometriosis have shed light on various signaling pathways involved, none of the aforementioned drugs can be considered a valid therapeutic option for endometriosis patients. Indeed, some of the cited drugs with antiproliferative and antiangiogenic impacts are approved in humans for oncological indications, but the high risk of side effects and their incompatibility with reproductive age and conception chances make them unsuitable candidates for endometriosis treatment in young patients.

Various phytochemicals, including resveratrol and naringenin, have also been tested in endometriosis models. Suppression of lesion growth was observed in preclinical studies with resveratrol thanks to its antiproliferative and antiangiogenic properties [74,75]. Naringenin is an antioxidant drug with antiproliferative and antioxidant effects. It acts by curbing Nrf2/KEAP1 pathway activation, decreasing cytoprotection from ROS, and favoring apoptosis. A reduction in endometriotic lesions through modulation of this pathway has been demonstrated in a rat model of endometriosis [70,71].

Other promising antioxidants with a safe pharmacological profile can be extracted from plants. Among them, curcumin has been widely tested in numerous pathological conditions for its anticancer, anti-inflammatory, and antioxidant properties [83]. Studies in rodents have proved the ability of curcumin to reduce endometriotic lesions through its antiangiogenic [66] and proapoptotic action [67]. However, the same characteristics were not confirmed in other experimental models using human endometrial cells [83,84]. Such divergent outcomes may be explained by low curcumin bioavailability and rapid metabolism in humans [83]. Further investigations are needed to determine whether this molecule, associated with pharmacological strategies such as liposomes or nanoparticles to enhance its bioavailability, could be a good candidate for neoadjuvant antioxidant therapy in patients with endometriosis.

Inhibiting oxidative stress with an impact on the proliferative phenotype was also attempted using N-acetylcysteine (NAC), which is not only known as an antioxidant drug but has also been shown to exert antiproliferative effects on cancer cells of epithelial origin [85]. NAC demonstrated antioxidant and antiproliferative activity in animal models of endometriosis by downregulating ERK1/2 kinase activity [72]. NAC treatment was then tried on women diagnosed with ovarian endometriosis and yielded a significant reduction in endometriotic cyst volume and endometriosis-related pain [73]. 


\subsection{Iron Overload}

The presence of iron conglomerates in endometriotic lesions inducing oxidative stress in the pelvic cavity may play a crucial role not only in endometriosis pathogenesis but also in disease progression [40-43]. Iron overload activates proinflammatory signaling, such as NFkB and interleukin (IL)-1 $\beta$, and triggers proliferation through cell cycle progression [86,87]. Iron chelators have been shown to mitigate iron overload effects, including excessive proliferation, serving as potential treatment options for cancer therapy $[88,89]$ (Table 1). Among iron chelators, desferrioxamine was able to reduce iron deposits and decrease the proliferation rate of glandular cells in endometriotic lesions in a murine model [40]. Iron overload in endometriosis was also targeted by erastin, a molecule able to boost ROS levels in the presence of iron accumulation to initiate ferroptosis, a cell death mechanism based on lethal peroxidation accumulation [90]. Erastin was found to induce ferroptosis in human endometrioma-derived cells in vitro and reduce the volume of endometriotic lesions in a murine model [68].

\section{Treatment of Chronic Pain by Decreasing Macrophage Activity}

The innate immune response is considered a central player in the pathophysiology of endometriosis since it involves proliferation and vascularization signaling in lesions [2,91]. In the presence of pelvic endometriosis, macrophage activation in the peritoneal cavity might promote oxidative stress, generating lipids and various proteins, including low-density lipoprotein peroxidation [15,91]. Non-neuronal cells such as mast cells and macrophages play an active role in pain in ectopic endometrium, through the release of proinflammatory cytokines such as tumor necrosis factor $\alpha$ (TNF- $\alpha$ ) and IL-1 $\beta$, and growth factors such as insulin growth factor 1 (IGF-1), resulting in nerve fiber recruitment and neuroinflammation [92-96]. These are key mechanisms for the development and maintenance of chronic pain [97]. Indeed, repeated stimuli lead to the enhanced responsiveness of pain nerve fibers, with an increase in their excitability, causing pain hypersensitivity and endometriotic lesion-related allodynia [98,99].

Based on the hypothesis that chronic inflammation plays a key role in endometriosis progression and associated hyperalgesia through macrophage activation, numerous experiments have been conducted in attempts to modulate the immune response in endometriosis models. While immune response modulation by administration of T-cell regulatory drugs such as IL- 2 and interferon $\alpha$ (IFN $\alpha$ ) did not have any impact on endometriotic lesions in clinical trials $[100,101]$, strategies able to regulate upstream triggers of the immune response, such as macrophages and mast cells, have yielded promising results (Table 2).

Peritoneal macrophage depletion was achieved using delivery systems such as liposomal bisphosphonate [102] and liposomal clodronate [96], which ensure drug delivery to phagocytic cells while minimizing toxicity in non-phagocytic cells. A decrease in endometriotic implants and systemic production of proinflammatory cytokines were observed with this therapeutic strategy in induced endometriosis in mice $[96,102]$. The role of IGF-1 in macrophage polarization and neurogenic activity as a nerve-sensitizing factor in an endometriosis-related inflammatory environment was also explored. Activated macrophage inhibition was achieved by the administration of linsitinib, an IGF-1 receptor inhibitor, resulting in endometriosis-associated pain alleviation and reduced nerve growth [96]. 
Table 2. Drugs decreasing macrophage and mast cell infiltration and activation.

\begin{tabular}{|c|c|c|c|c|}
\hline Reference & Drug & Effect & Endometriosis Source & Experimental Model \\
\hline $\begin{array}{l}\text { Haber et al., } 2009 \\
\text { [102] }\end{array}$ & $\begin{array}{l}\text { Liposomal } \\
\text { bisphosphonate }\end{array}$ & $\begin{array}{l}\text { Decline in endometriotic lesion volume } \\
\text { less macrophage infiltration }\end{array}$ & Rodent (rat) & $\begin{array}{l}\text { Autotransplantation rat } \\
\text { model }\end{array}$ \\
\hline $\begin{array}{l}\text { Foster et al., } 2019 \\
\text { [96] }\end{array}$ & $\begin{array}{l}\text { Liposomal clodronate } \\
\text { Linsitinib }\end{array}$ & $\begin{array}{l}\text { Less macrophage infiltration } \\
\text { Decrease in IGF-1 expression } \\
\text { Attenuation of hyperalgesia }\end{array}$ & $\begin{array}{l}\text { Human (pelvic } \\
\text { endometriotic lesions) }\end{array}$ & $\begin{array}{l}\text { In vitro culture; } \\
\text { xenotransplantation } \\
\text { murine model }\end{array}$ \\
\hline $\begin{array}{l}\text { Ihara et al., } 2004 \\
\text { [103] }\end{array}$ & $\begin{array}{l}\text { Leukotriene receptor } \\
\text { antagonists }\end{array}$ & $\begin{array}{c}\text { Lower stromal proliferation rates } \\
\text { Decline in mast cell infiltration } \\
\text { and activation }\end{array}$ & Rodent (rat) & $\begin{array}{l}\text { Autotransplantation rat } \\
\text { model }\end{array}$ \\
\hline $\begin{array}{c}\text { Guney et al., } 2008 \\
{[104]}\end{array}$ & Melatonin & $\begin{array}{c}\text { Decline in endometriotic lesion volume } \\
\text { Increased SOD and CAT activity } \\
\text { Lower MDA levels }\end{array}$ & Rodent (rat) & $\begin{array}{l}\text { Autotransplantation rat } \\
\text { model }\end{array}$ \\
\hline $\begin{array}{l}\text { Yildirim et al., } 2009 \\
\text { [105] }\end{array}$ & Melatonin & $\begin{array}{c}\text { Decline in endometriotic lesion volume } \\
\text { Increased SOD and CAT activity } \\
\text { Alleviation of chronic pain }\end{array}$ & Rodent (rat) & $\begin{array}{l}\text { Autotransplantation rat } \\
\text { model }\end{array}$ \\
\hline $\begin{array}{l}\text { Schwertner et al., } \\
2013 \text { [106] }\end{array}$ & Melatonin & $\begin{array}{c}\text { Improvement in dysmenorrhea } \\
\text { and dyspareunia } \\
\text { Improvement in dyschezia and dysuria } \\
\text { Lower BDNF levels }\end{array}$ & $\begin{array}{l}\text { Human (pelvic } \\
\text { endometriotic lesions) }\end{array}$ & $\begin{array}{c}\text { Endometriosis patients } \\
\text { with chronic pain }\end{array}$ \\
\hline $\begin{array}{l}\text { Iuvone et al., } 2016 \\
\text { [107] }\end{array}$ & PEA & $\begin{array}{l}\text { Decrease in mast cell numbers } \\
\text { Decline in endometriotic lesion volume }\end{array}$ & Rodent (rat) & $\begin{array}{l}\text { Autotransplantation rat } \\
\text { model }\end{array}$ \\
\hline $\begin{array}{l}\text { Idraccolo et al., } 2017 \\
\text { [108] }\end{array}$ & PEA + polydatin & $\begin{array}{c}\text { Alleviation of chronic pain } \\
\text { Improvement in dysmenorrhea } \\
\text { and dyspareunia } \\
\text { No improvement in dyschezia }\end{array}$ & $\begin{array}{l}\text { Human (pelvic } \\
\text { endometriotic lesions) }\end{array}$ & $\begin{array}{l}\text { Endometriosis patients } \\
\text { with chronic pain }\end{array}$ \\
\hline
\end{tabular}

PEA, ultramicronized palmitoylethanolamide; IGF-1, insulin growth factor 1; SOD, superoxide dismutase; CAT, catalase; MDA, malondialdehyde; BDNF, brain-derived neurotrophic factor.

Some drugs act as mast cell stabilizers, reducing their activation and degranulation of proinflammatory cytokines. A number of mast cell stabilizers, such as leukotriene receptor antagonists [103] and ultramicronized palmitoylethanolamide (PEA) [107], have been tested on endometriosis models in preclinical studies. They had a positive impact on chronic pain through a significant reduction in mast cell degranulation and release of cytokines such as TNF- $\alpha$, but there was no decrease in endometriotic lesion size [108]. Clinical studies on PEA combined with polydatin, another mast cell stabilizer, do suggest some effect on endometriosis-related pain [108], but further studies need to validate this therapeutic approach prior to introduction into clinical practice $[95,109]$.

Some antioxidants with pleiotropic effects on neuroinflammation have also been considered as potential therapeutic options. Among them, melatonin is an antioxidant and anti-inflammatory drug able to modulate levels of several cytokines [110], including brainderived neurotrophic factor (BDNF), a neuromediator playing a central role in hyperalgesia sensitization, and hence in chronic pain [111,112]. Melatonin modulation of BDNF may be of special interest in endometriosis, as it is partially dependent on estrogen variations and steroidogenesis $[106,111]$. Studies in animal models have shown melatonin to induce regression and atrophy of endometriotic lesions [104,105]. Administration of melatonin for 8 weeks also proved effective at reducing discomfort in patients with endometriosis and suffering chronic pelvic pain [106].

Although further investigations need to establish whether targeting macrophages is a valid therapeutic option for endometriosis treatment, preliminary results look promising, possibly involving a role for such a strategy in slowing disease progression and relieving chronic pain-related symptomatology.

\section{Targeting Oxidative Stress to Treat Endometriosis-Related Infertility}

Endometriosis may affect fertility potential in numerous ways. Pelvic anatomy alterations due to adhesions and tubal dysfunction, a diminished ovarian reserve with lower oocyte and embryo quality, along with decreased implantation and pregnancy rates because of endometrial receptivity alterations, have been widely investigated as a cause of endometriosis-related infertility $[20,113]$ (Figure 3). 


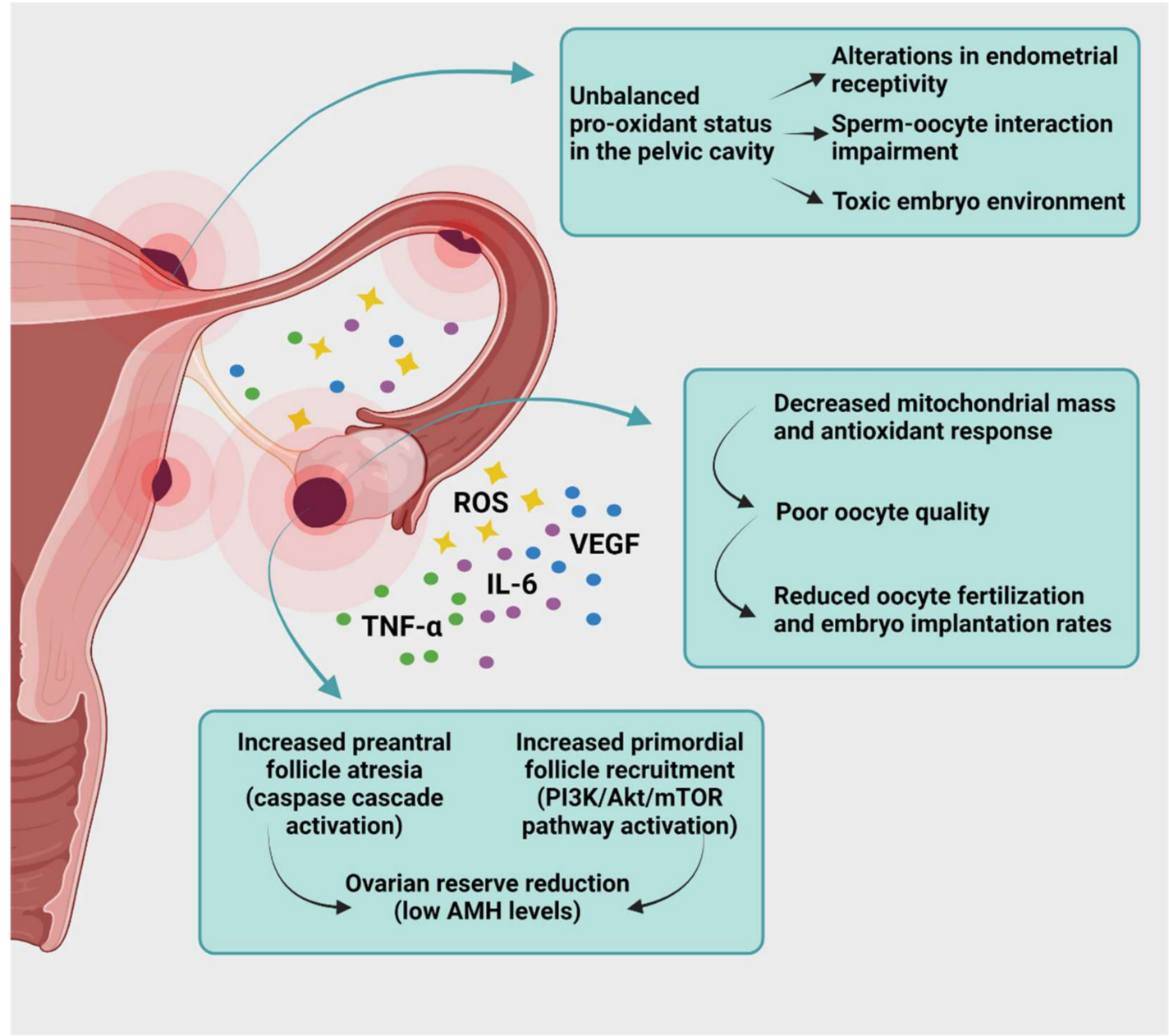

Figure 3. Endometriosis and infertility. Impact of ROS and inflammatory cytokines on the reproductive tract of patients with pelvic and ovarian endometriosis. Endometriosis affects the ovarian reserve and quality of oocytes and contributes to a toxic pelvic environment, reducing the chances of fertilization and implantation: ROS, reactive oxygen species; TNF- $\alpha$, tumor necrosis factor $\alpha$; IL-6, interleukin 6; PI3K/Akt/mTOR, phosphoinositol 3-kinase/protein kinase B/mammalian target of rapamycin; AMH, anti-Müllerian hormone. Created with biorender.com (accessed on 28 May 2021).

The ovarian reserve, namely the number of primordial follicles that are quiescent in the cortex, may be negatively impacted by surgical ablation of endometriomas, with a significant drop in anti-Müllerian hormone (AMH) levels [114,115]. However, the ovarian reserve has been found to be reduced in subjects even before surgery [115], and its accelerated depletion is associated with the presence of endometriomas and fibrosis in cortical tissue, the latter being the consequence of both chronic inflammation and oxidative stress [116]. Increased follicle recruitment and atresia were indeed observed in the ovarian cortex close to endometriomas compared with the contralateral ovary [117], resulting in focal exhaustion of early-stage follicles. Numerous cytokines and molecules that favor ectopic lesion hyperproliferation, such as VEGF, IL-6, and TNF- $\alpha$, may support accelerated follicle activation in the surrounding healthy ovarian cortex, as well as triggering the PI3K/Akt/mTOR signaling pathway involved in primordial follicle recruitment [118]. Moreover, ROS can directly modulate the ovarian reserve, not only by enhancing the proinflammatory environment and PI3K/Akt/mTOR pathway activation $[119,120]$ but also by precipitating cell death due to cumulative DNA damage [121,122]. Intraovarian oxidative stress is further compounded around endometriomas by the presence of increased uncoupled iron levels resulting from the imbalance between iron storage mechanisms and its reactivity [123]. 
A reduced ovarian reserve due to the presence of endometriomas or as a consequence of their surgical ablation only partially explains poor IVF results in women with endometriosis. Indeed, recently published data on IVF outcomes revealed lower oocyte survival, embryo development, and clinical pregnancy rates in younger ( $<35$ years) endometriosis patients who had undergone fertility preservation by oocyte vitrification, compared with those undergoing elective fertility preservation [124]. This suggests that impaired oocyte quality and implantation may well play an important role in the pathogenesis of endometriosis-related infertility.

Oocyte quality depends on mitochondrial function and enzymatic setting to balance intracellular ROS levels [125]. Mature oocytes from women with endometriosis are characterized by more abnormal mitochondria, decreased mitochondrial mass [126,127], and differing expression of patterns regulating antioxidant response [128]. These aspects are crucial to fertility potential, as impaired mitochondrial function may impact energy production and lead to oocyte arrest and degeneration during the fertilization process.

The other key element is endometrial receptivity due to endometriosis-sustained chronic pelvic inflammation [129]. Peritoneal fluid from women with endometriosis has pro-oxidant status due to an imbalance between ROS generation and antioxidant defense systems, resulting in less efficient protection of oocytes. Antioxidants such as vitamin C, vitamin $\mathrm{E}$, thioredoxin, $\mathrm{SOD}$, and glutathione have been found to be lower in follicular fluid from infertile patients with endometriosis than in women with non-endometriosisrelated infertility [130-133]. Despite robust evidence showing altered redox balance in the pelvic and intrafollicular environment in the case of endometriosis, supplementation with immunomodulators able to decrease inflammation and oxidative stress, such as pentoxifylline [134], or indeed antioxidants such as vitamin C and E [135,136], failed to yield any advantage in terms of pregnancy rates.

\section{Conclusions}

Recent literature on the subject supports the notion that oxidative stress plays a key role in the pathogenesis of endometriosis and its evolution and symptom presentation. The main symptoms of endometriosis, namely chronic pain and infertility, are contingent on the establishment of chronic inflammation, with dysregulation of the immune system and multiple cell functions, including the control of ROS generation. Targeting oxidative stress could prove a winning strategy to manage both endometriotic lesion progression by curbing the hyperproliferative phenotype acquired by endometrial cells and inhibiting iron overload, and also endometriosis-associated symptoms. Chronic pain and hyperalgesia may be mitigated by innate immune response modulation, focusing particularly on macrophages and mast cells. Regarding infertility, there is growing evidence that oxidative stress is involved in accelerated follicle depletion, poor oocyte quality, and lower fertilization rates. Our increased understanding will undoubtedly lead to improved treatments in the near future, thanks to novel therapeutic strategies targeting ROS imbalance and impaired mitochondrial function.

Author Contributions: Conceptualization, L.C. and J.D.; methodology, L.C.; investigation, L.C.; data curation, L.C.; writing-original draft preparation, L.C.; writing-review and editing, J.D. and M.-M.D.; supervision, M.-M.D. All authors have read and agreed to the published version of the manuscript.

Funding: This study was supported by grants from the Fonds National de la Recherche Scientifique de Belgique (grant 5/4/150/5 awarded to Marie-Madeleine Dolmans, and F.R.S.-FNRS/FRIA FC29657 awarded to Luciana Cacciottola).

Acknowledgments: The authors thank Mira Hryniuk, BA, for reviewing the English language of the article.

Conflicts of Interest: The authors declare no conflict of interest. 


\section{References}

1. Zondervan, K.T.; Becker, C.M.; Missmer, S.A. Endometriosis. N. Engl. J. Med. 2020, 382, 1244-1256. [CrossRef] [PubMed]

2. Taylor, H.S.; Kotlyar, A.M.; Flores, V.A. Endometriosis is a chronic systemic disease: Clinical challenges and novel innovations. Lancet 2021, 397, 839-852. [CrossRef]

3. Giudice, L.C. Clinical practice. Endometriosis. N. Engl. J. Med. 2010, 362, 2389-2398. [CrossRef] [PubMed]

4. Shafrir, A.L.; Farland, L.V.; Shah, D.K.; Harris, H.R.; Kvaskoff, M.; Zondervan, K.; Missmer, S.A. Risk for and consequences of endometriosis: A critical epidemiologic review. Best Pract. Res. Clin. Obstet. Gynaecol. 2018, 51, 1-15. [CrossRef]

5. Simoens, S.; Dunselman, G.; Dirksen, C.; Hummelshoj, L.; Bokor, A.; Brandes, I.; Brodszky, V.; Canis, M.; Colombo, G.L.; DeLeire, T.; et al. The burden of endometriosis: Costs and quality of life of women with endometriosis and treated in referral centres. Hum. Reprod. 2012, 27, 1292-1299. [CrossRef]

6. Beliard, A.; Donnez, J.; Nisolle, M.; Foidart, J.M. Localization of laminin, fibronectin, E-cadherin and integrins in endometrium and endometriosis. Fertil. Steril. 1997, 67, 266-272. [CrossRef]

7. Klemmt, P.A.B.; Carver, J.G.; Koninckx, P.; McVeigh, E.J.; Mardon, H.J. Endometrial cells from women with endometriosis have increased adhesion and proliferative capacity in response to extracellular matrix components: Towards a mechanistic model for endometriosis progression. Hum. Reprod. 2007, 22, 3139-3147. [CrossRef]

8. Kokorine, I.; Nisolle, M.; Donnez, J.; Eeckhout, Y.; Courtoy, P.J.; Marbaix, E. Expression of interstitial collagenase (matrix metalloproteinase-1) is related to the activity of human endometriotic lesions. Fertil. Steril. 1997, 68, 246-251. [CrossRef]

9. Sillem, M.; Prifti, S.; Neher, M.; Runnebaum, B. Extracellular matrix remodelling in the endometrium and its possible relevance to the pathogenesis of endometriosis. Hum. Reprod. Update 1998, 4, 730-735. [CrossRef]

10. Reis, F.M.; Petraglia, F.; Taylor, R.N. Endometriosis: Hormone regulation and clinical consequences of chemotaxis and apoptosis. Hum. Reprod. Update 2013, 19, 406-418. [CrossRef]

11. Han, S.J.; Jung, S.Y.; Wu, S.-P.; Hawkins, S.M.; Park, M.J.; Kyo, S.; Qin, J.; Lydon, J.P.; Tsai, S.Y.; Tsai, M.J.; et al. Estrogen receptor $\beta$ modulates apoptosis complexes and the inflammasome to drive the pathogenesis of endometriosis. Cell 2015, 163, 960-974. [CrossRef]

12. Donnez, J.; Smoes, P.; Gillerot, S.; Casanas-Roux, F.; Nisolle, M. Vascular endothelial growth factor (VEGF) in endometriosis. Hum. Reprod. 1998, 13, 1686-1690. [CrossRef]

13. Symons, L.K.; Miller, J.E.; Kay, V.R.; Marks, R.M.; Liblik, K.; Koti, M.; Tayade, C. The immunopathophysiology of endometriosis. Trends Mol. Med. 2018, 24, 748-762. [CrossRef]

14. Vinatier, D.; Cosson, M.; Dufour, P. Is endometriosis an endometrial disease? Eur. J. Obstet. Gynecol. Reprod. Biol. 2000, 91, 113-125. [CrossRef]

15. Murphy, A.A.; Santanam, N.; Parthasarathy, S. Endometriosis: A disease of oxidative stress? Semin. Reprod. Endocrinol. 1998, 16, 263-273. [CrossRef]

16. Van Langendonckt, A.; Casanas-Roux, F.; Donnez, J. Oxidative stress and peritoneal endometriosis. Fertil. Steril. 2000, 77, 861-870. [CrossRef]

17. Donnez, J.; Binda, M.M.; Donnez, O.; Dolmans, M.M. Oxidative stress in the pelvic cavity and its role in the pathogenesis of endometriosis. Fertil. Steril. 2016, 106, 1011-1017. [CrossRef]

18. Nisolle, M.; Donnez, J. Peritoneal endometriosis, ovarian endometriosis, and adenomyotic nodules of the rectovaginal septum are three different entities. Fertil. Steril. 1997, 68, 585-596. [CrossRef]

19. American Society for Reproductive Medicine. Revised American society for reproductive medicine classification of endometriosis: 1996. Fertil. Steril. 1997, 67, 817-821. [CrossRef]

20. de Ziegler, D.; Borghese, B.; Chapron, C. Endometriosis and infertility: Pathophysiology and management. Lancet 2010, 376, 730-738. [CrossRef]

21. Maignien, C.; Santulli, P.; Gayet, V.; Lafay-Pillet, M.C.; Korb, D.; Bourdon, M.; Marcellin, L.; de Ziegler, D.; Chapron, C. Prognostic factors for assisted reproductive technology in women with endometriosis-related infertility. Am. J. Obstet. Gynecol. 2017, 216, 280.e1-280.e9. [CrossRef] [PubMed]

22. Maignien, C.; Santulli, P.; Marcellin, L.; Korb, D.; Bordonne, C.; Dousset, B.; Bourdon, M.; Chapron, C. Infertility in women with bowel endometriosis: First-line assisted reproductive technology results in satisfactory cumulative live-birth rates. Fertil. Steril. 2021, 115, 692-701. [CrossRef] [PubMed]

23. The Practice Committee of the American Society for Reproductive Medicine. Endometriosis and infertility: A committee opinion. Fertil. Steril. 2012, 98, 591-598.

24. Bostek, C.C. Oxygen toxicity: An introduction. AANA J. 1989, 57, 231-237.

25. Ruder, E.H.; Hartman, T.J.; Blumberd, J.; Goldman, M.B. Oxidative stress and antioxidants: Exposure and impact on female fertility. Hum. Reprod. Update 2008, 14, 345-357. [CrossRef]

26. Agarwal, A.; Aponte-Mellado, A.; Premkumar, B.J.; Shaman, A.; Gupta, S. The effects of oxidative stress on female reproduction: A review. Reprod. Biol. Endocrinol. 2012, 10, 49. [CrossRef]

27. Aon, M.A.; Cortassa, S.; O'Rourke, B. Redox-optimized ROS balance: A unifying hypothesis. Biochim. Biophys. Acta 2010, 1797, 865-877. [CrossRef]

28. Iwabuchi, T.; Yoshimoto, C.; Shigetomi, H.; Kobayashi, H. Oxidative stress and antioxidant defense in endometriosis and its malignant transformation. Oxid. Med. Cell Longev. 2015, 2015, 848595. [CrossRef] 
29. Martinez, V.D.; Vucic, E.A.; Thu, K.L.; Pikor, L.A.; Hubaux, R.; Lam, W.L. Unique Pattern of Component Gene Disruption in the NRF2 Inhibitor KEAP1/CUL3/RBX1 E3-Ubiquitin Ligase Complex in Serous Ovarian Cancer. Biomed. Res. Int. 2014, $2014,159459$. [CrossRef]

30. Li, W.; Yu, S.; Liu, T.; Kim, J.H.; Blank, V.; Li, H.; Kong, A.N.T. Heterodimerization with Small Maf Proteins Enhances Nuclear Retention of Nrf2 via Masking the NESzip Motif. Biochim. Biophys. Acta 2008, 1783, 1847-1856. [CrossRef]

31. González-Ramos, R.; Van Langendonckt, A.; Defrère, S.; Lousse, J.C.; Colette, S.; Devoto, L.; Donnez, J. Involvement of the nuclear factor-КB pathway in the pathogenesis of endometriosis. Fertil. Steril. 2010, 94, 1985-1994. [CrossRef]

32. Gonzalez-Ramos, R.; Donnez, J.; Defrere, S.; Leclercq, I.; Squifflet, J.; Lousse, J.C.; Van Langendonckt, A. Nuclear factor-kappa B (NF-kB) is constitutively activated in peritoneal endometriosis. Mol. Hum. Reprod. 2007, 13, 503-509. [CrossRef]

33. Lousse, J.C.; Van Langendonckt, A.; Defrere, S.; Gonzalez Ramos, R.; Colette, S.; Donnez, J. Peritoneal endometriosis is an inflammatory disease. Front. Biosci. 2012, 4, 23-40. [CrossRef]

34. Lousse, J.C.; Van Langendonckt, A.; Gonzalez-Ramos, R.; Defrere, S.; Renkin, E.; Donnez, J. Increased activation of nuclear factor-kappa B (NF-kappaB) in isolated peritoneal macrophages of patients with endometriosis. Fertil. Steril. 2008, 90, 217-220. [CrossRef]

35. Harlev, A.; Gupta, S.; Agarwal, A. Targeting oxidative stress to treat endometriosis. Expert Opin. Ther. Targets 2015, 19, 1447-1464. [CrossRef]

36. Carvalho, L.F.; Samadder, A.N.; Agarwal, A.; Fernandes, L.F.; Abrao, M.S. Oxidative stress biomarkers in patients with endometriosis: Systematic review. Arch. Gynecol. Obstet. 2012, 286, 1033-1040. [CrossRef]

37. Lambrinoudaki, I.V.; Augoulea, A.; Christodoulakos, G.E.; Economou, E.V.; Kaparos, G.; Kontoravdis, A.; Papadias, C.; Creatsas, G. Measurable serum markers of oxidative stress response in women with endometriosis. Fertil. Steril. 2009, 91, 46-50. [CrossRef]

38. Yamawaki, H.; Pan, S.; Lee, R.T.; Berk, B.C. Fluid shear stress inhibits vascular inflammation by decreasing thioredoxin-interacting protein in endothelial cells. J. Clin. Investig. 2005, 115, 733-738. [CrossRef]

39. Santulli, P.; Chouzenoux, S.; Fiorese, M.; Marcellin, L.; Lemarechal, H.; Millischer, A.E.; Batteux, F.; Borderie, D.; Chapron, C. Protein oxidative stress markers in peritoneal fluids of women with deep infiltrating endometriosis are increased. Hum. Reprod. 2015, 30, 49-60. [CrossRef]

40. Defrere, S.; Van Langendonckt, A.; Vaesen, S.; Jouret, M.; Gonzalez Ramos, R.; Gonzalez, D.; Donnez, J. Iron overload enhances epithelial cell proliferation in endometriotic lesions induced in a murine model. Hum. Reprod. 2006, 21, 2810-2816. [CrossRef]

41. Van Langendonckt, A.; Casanas-Roux, F.; Dolmans, M.M.; Donnez, J. Potential involvement of hemoglobin and heme in the pathogenesis of peritoneal endometriosis. Fertil. Steril. 2002, 77, 561-570. [CrossRef]

42. Van Langendonckt, A.; Casanas-Roux, F.; Donnez, J. Iron overload in the peritoneal cavity of women with pelvic endometriosis. Fertil. Steril. 2002, 78, 712-718. [CrossRef]

43. Van Langendonckt, A.; Casanas-Roux, F.; Eggermont, J.; Donnez, J. Characterization of iron deposition in endometriotic lesions induced in the nude mouse model. Hum. Reprod. 2004, 19, 1265-1271. [CrossRef]

44. Koninckx, P.R.; Donnez, J.; Brosens, I. Microscopic endometriosis: Impact on our understanding of the disease and its surgery. Fertil. Steril. 2016, 105, 305-306. [CrossRef]

45. Lousse, J.C.; Defrere, S.; Van Langendonckt, A.; Gras, J.; Gonzalez-Ramos, R.; Colette, S.; Donnez, J. Iron storage is significantly increased in peritoneal macrophages of patients with endometriosis and correlates with iron overload in the peritoneal fluid Fertil. Steril. 2009, 91, 1668-1675. [CrossRef]

46. Levy, A.P.; Levy, J.E.; Kalet-Litman, S.; Miller-Lotan, R.; Levy, N.S.; Asaf, R.; Guetta, J.; Yang, C.; Purushothaman, K.R.; Fuster, V.; et al. Haptoglobin genotype is a determinant of iron, lipid peroxidation, and macrophage accumulation in the atherosclerotic plaque. Arterioscler. Thromb. Vasc. Biol. 2007, 27, 134-140. [CrossRef]

47. Defrere, S.; Lousse, J.C.; Gonzalez-Ramos, R.; Colette, S.; Donnez, J.; Van Langendonckt, A. Potential involvement of iron in the pathogenesis of peritoneal endometriosis. Mol. Hum. Reprod. 2008, 14, 377-385. [CrossRef]

48. Balla, G.; Jacob, H.S.; Balla, J.; Rosenberg, M.; Nath, K.; Apple, F.; Eaton, J.W.; Vercellotti, G.M. Ferritin: A cytoprotective antioxidant stratagem of endothelium. J. Biol. Chem. 1992, 267, 18148-18153. [CrossRef]

49. Potts, M.B.; Koh, S.E.; Whetstone, W.D.; Walker, B.A.; Yoneyama, T.; Claus, C.P.; Manvelyan, H.M.; Noble-Haeusslein, L.J. Traumatic injury to the immature brain: Inflammation, oxidative injury, and iron-mediated damage as potential therapeutic targets. NeuroRx 2006, 3, 143-153. [CrossRef] [PubMed]

50. Arumugam, K.; Yip, Y.C. De novo formation of adhesions in endometriosis: The role of iron and free radical reactions. Fertil. Steril. 1995, 64, 62-64. [CrossRef]

51. Buttke, T.M.; Sandstrom, P.A. Oxidative stress as a mediator of apoptosis. Immunol. Today 1994, 15, 7-10. [CrossRef]

52. Agarwal, A.; Gupta, S.; Sharma, R. Role of oxidative stress in female reproduction. Reprod. Biol. Endocrinol. $2005,3,1-21$. [CrossRef]

53. Wagener, F.A.; Volk, H.D.; Willis, D.; Abraham, N.G.; Soares, M.P.; Adema, G.J.; Figdor, C.G. Different faces of the heme-heme oxygenase system in inflammation. Pharmacol. Rev. 2003, 55, 551-571. [CrossRef]

54. Stocker, R.; Glazer, A.N.; Ames, B.N. Antioxidant activity of albumin-bound bilirubin. Proc. Natl. Acad. Sci. USA 1987, 84, 5918-5922. [CrossRef] 
55. Nakahira, K.; Takahashi, T.; Shimizu, H.; Maeshima, K.; Uehara, K.; Fujii, H.; Nakatsuka, H.; Yokoyama, M.; Akagi, R.; Morita, K. Protective role of heme oxygenase-1 induction in carbon tetrachlorideinduced hepatotoxicity. Biochem. Pharmacol. 2003, 15, 1091-1105. [CrossRef]

56. Swiersz, L.M. Role of endometriosis in cancer and tumor development. Ann. N. Y. Acad. Sci. 2002, 955, 281-292, discussions 293-5, 396-406. [CrossRef]

57. Donnez, J.; Dolmans, M.M. Endometriosis and Medical Therapy: From Progestogens to Progesterone Resistance to GnRH Antagonists: A Review. J. Clin. Med. 2021, 10, 1085. [CrossRef]

58. National Guideline Alliance. Endometriosis: Diagnosis and Management; National Institute for Health and Care Excellence: London, UK, 2017.

59. Bouchard, P.; Chabbert-Buffet, N.; Fauser, B.C. Selective progesterone receptor modulators in reproductive medicine: Pharmacology, clinical efficacy and safety. Fertil. Steril. 2011, 96, 1175-1189. [CrossRef]

60. Ngô, C.; Chéreau, C.; Nicco, C.; Weill, B.; Chapron, C.; Batteux, F. Reactive oxygen species controls endometriosis progression. Am. J. Pathol. 2009, 175, 225-234. [CrossRef]

61. McCubrey, J.A.; Lahair, M.M.; Franklin, R.A. Reactive oxygen speciesinduced activation of the MAP kinase signaling pathways. Antioxid. Redox. Signal. 2006, 8, 1775-1789. [CrossRef]

62. Murk, W.; Atabekoglu, C.S.; Cakmak, H.; Heper, A.; Ensari, A.; Kayisli, U.A.; Arici, A. ERK activity in the human endometrium: Possible roles in the pathogenesis of endometriosis. J. Clin. Endocrinol. Metab. 2008, 93, 3532-3540. [CrossRef]

63. Gentilini, D.; Busacca, M.; Di Francesco, S.; Vignali, M.; Vigano, P.; Di Blasio, A.M. PI3K/Akt and ERK1/2 signalling pathways are involved in endometrial cell migration induced by 17beta-estradiol and growth factors. Mol. Hum. Reprod. 2007, 13, 317-322. [CrossRef]

64. Ngô, C.; Nicco, C.; Leconte, M.; Chéreau, C.; Arkwright, S.; Vacher-Lavenu, M.C.; Weill, B.; Chapron, C.; Batteux, F. Protein kinase inhibitors can control the progression of endometriosis in vitro and in vivo. J. Pathol. 2010, 222, 148-157. [CrossRef]

65. Leconte, M.; Nicco, C.; Ngô, C.; Arkwright, S.; Chéreau, C.; Guibourdenche, J.; Weill, B.; Chapron, C.; Dousset, B.; Batteux, F. Antiproliferative effects of cannabinoid agonists on deep infiltrating endometriosis. Am. J. Pathol. 2010, 177, 2963-2970. [CrossRef]

66. Zhang, Y.; Cao, H.; Hu, Y.Y.; Wang, H.; Zhang, C.J. Inhibitory effect of curcumin on angiogenesis in ectopic endometrium of rats with experimental endometriosis. Int. J. Mol. Med. 2011, 27, 87-94. [CrossRef]

67. Jana, S.; Paul, S.; Swarnakar, S. Curcumin as anti-endometriotic agent: Implication of MMP-3 and intrinsic apoptotic pathway. Biochem. Pharmacol. 2012, 83, 797-804. [CrossRef]

68. Li, Y.; Zeng, X.; Lu, D.; Yin, M.; Shan, M.; Gao, Y. Erastin induces ferroptosis via ferroportin-mediated iron accumulation in endometriosis. Hum. Reprod. 2020, 36, 951-964. [CrossRef]

69. Leconte, M.; Nicco, C.; Ngô, C.; Chéreau, C.; Chouzenoux, S.; Marut, W.; Guibourdenche, J.; Arkwright, S.; Weill, B.; Chapron, C.; et al. The mTOR/AKT inhibitor temsirolimus prevents deep infiltrating endometriosis in mice. Am. J. Pathol. 2011, 179, 880-889. [CrossRef]

70. Park, S.; Lim, W.; Bazer, F.W.; Song, G. Naringenin induces mitochondria-mediated apoptosis and endoplasmic reticulum stress by regulating MAPK and AKT signal transduction pathways in endometriosis cells. Mol. Hum. Reprod. 2017, 23, 842-854. [CrossRef]

71. Kapoor, R.; Sirohi, V.K.; Gupta, K.; Dwivedi, A. Naringenin ameliorates progression of endometriosis by modulating Nrf2/Keap1/HO1 axis and inducing apoptosis in rats. J. Nutr. Biochem. 2019, 70, 215-226. [CrossRef]

72. Pittaluga, E.; Costa, G.; Krasnowska, E.; Brunelli, R.; Lundeberg, T.; Porpora, M.G.; Santucci, D.; Parasassi, T. More than antioxidant: N-acetyl-L-cysteine in a murine model of endometriosis. Fertil. Steril. 2010, 94, 2905-2908. [CrossRef] [PubMed]

73. Porpora, M.G.; Brunelli, R.; Costa, G.; Imperiale, L.; Krasnowska, E.K.; Lundeberg, T.; Nofroni, I.; Piccioni, M.G.; Pittaluga, E.; Ticino, A.; et al. A promise in the treatment of endometriosis: An observational cohort study on ovarian endometrioma reduction by $\mathrm{N}$-acetylcysteine. Evid. Based Complement. Alternat. Med. 2013, 2013, 240702. [CrossRef] [PubMed]

74. Rudzitis-Auth, J.; Menger, M.D.; Laschke, M.W. Resveratrol is a potent inhibitor of vascularization and cell proliferation in experimental endometriosis. Hum. Reprod. 2013, 28, 1339-1347. [CrossRef] [PubMed]

75. Taguchi, A.; Wada-Hiraike, O.; Kawana, K.; Koga, K.; Yamashita, A.; Shirane, A.; Urata, Y.; Kozuma, S.; Osuga, Y.; Fujii, T. Resveratrol suppresses inflammatory responses in endometrial stromal cells derived from endometriosis: A possible role of the sirtuin 1 pathway. J. Obstet. Gynaecol. Res. 2014, 40, 770-778. [CrossRef] [PubMed]

76. Ozer, H.; Boztosun, A.; Acmaz, G.; Atilgan, R.; Akkar, O.B.; Kosar, M.I. The efficacy of bevacizumab, sorafenib, and retinoic acid on rat endometriosis model. Reprod. Sci. 2013, 20, 26-32. [CrossRef] [PubMed]

77. Yildiz, C.; Kacan, T.; Akkar, O.B.; Karakus, S.; Kacan, S.B.; Ozer, H.; Cetin, A. Effects of Pazopanib, Sunitinib, and Sorafenib, Anti-VEGF Agents, on the Growth of Experimental Endometriosis in Rats. Reprod. Sci. 2015, 22, 1445-1451. [CrossRef] [PubMed]

78. Leconte, M.; Santulli, P.; Chouzenoux, S.; Marcellin, L.; Cerles, O.; Chapron, C.; Dousset, B.; Batteux, F. Inhibition of MAPK and VEGFR by Sorafenib Controls the Progression of Endometriosis. Reprod. Sci. 2015, 22, 1171-1180. [CrossRef] [PubMed]

79. Breedveld, F.C.; Dayer, J.M. Leflunomide: Mode of action in the treatment of rheumatoid arthritis. Ann. Rheum. Dis. 2000, 59, 841-849. [CrossRef]

80. Aytan, H.; Caglar, P.; Uygur, D.; Zergeroglu, S.; Batioglu, S. Effect of the immunomodulator leflunomide on the induction of endometriosis in an experimental rat model. Fertil. Steril. 2007, 87, 698-701. [CrossRef] 
81. Wilhelm, S.M.; Carter, C.; Tang, L.; Wilkie, D.; McNabola, A.; Rong, H.; Chen, C.; Zhang, X.; Vincent, P.; McHugh, M.; et al. BAY 43-9006 exhibits broad spectrum oral antitumor activity and targets the RAF/MEK/ERK pathway and receptor tyrosine kinases involved in tumor progression and angiogenesis. Cancer Res. 2004, 64, 7099-7109. [CrossRef]

82. Yagyu, T.; Tsuji, Y.; Haruta, S.; Kitanaka, T.; Yamada, Y.; Kawaguchi, R.; Kanayama, S.; Tanase, Y.; Kurita, N.; Kobayashi, H. Activation of mammalian target of rapamycin in postmenopausal ovarian endometriosis. Int. J. Gynecol. Cancer 2006, 16, 1545-1551. [CrossRef]

83. Vallée, A.; Lecarpentier, Y. Curcumin and Endometriosis. Int. J. Mol. Sci. 2020, 21, 2440. [CrossRef]

84. Kim, K.H.; Lee, E.N.; Park, J.K.; Lee, J.R.; Kim, J.H.; Choi, H.J.; Kim, B.S.; Lee, H.W.; Lee, K.S.; Yoon, S. Curcumin attenuates TNF- $\alpha$-induced expression of intercellular adhesion molecule-1, vascular cell adhesion molecule-1 and proinflammatory cytokines in human endometriotic stromal cells. Phytother. Res. 2012, 26, 1037-1047. [CrossRef]

85. Parasassi, T.; Brunelli, R.; Bracci-Laudiero, L.; Greco, G.; Gustafsson, A.C.; Krasnowska, E.K.; Lundeberg, J.; Lundeberg, T.; Pittaluga, E.; Romano, M.C.; et al. Differentiation of normal and cancer cells induced by sulfhydryl reduction: Biochemical and molecular mechanisms. Cell Death Differ. 2005, 12, 1285-1296. [CrossRef]

86. Alvarado-Díaz, C.P.; Núñez, M.T.; Devoto, L.; González-Ramos, R. Iron overload-modulated nuclear factor kappa-B activation in human endometrial stromal cells as a mechanism postulated in endometriosis pathogenesis. Fertil. Steril. 2015, 103, 439-447. [CrossRef]

87. Alvarado-Díaz, C.P.; Núñez, M.T.; Devoto, L.; González-Ramos, R. Endometrial expression and in vitro modulation of the iron transporter divalent metal transporter-1: Implications for endometriosis. Fertil. Steril. 2016, 106, 393-401. [CrossRef]

88. Abdelaal, G.; Veuger, S. Reversing oncogenic transformation with iron chelation. Oncotarget 2021, 12, 106-124. [CrossRef]

89. Ibrahim, O.; O'Sullivan, J. Iron chelators in cancer therapy. Biometals 2020, 33, 201-215. [CrossRef]

90. Dixon, S.J.; Lemberg, K.M.; Lamprecht, M.R.; Skouta, R.; Zaitsev, E.M.; Gleason, C.E.; Patel, D.N.; Bauer, A.J.; Cantley, A.M.; Yang, W.S.; et al. Ferroptosis: An iron-dependent form of nonapoptotic cell death. Cell 2012, 149, 1060-1072. [CrossRef]

91. Capobianco, A.; Monno, A.; Cottone, L.; Venneri, M.A.; Biziato, D.; Di Puppo, F.; Ferrari, S.; De Palma, M.; Manfredi, A.A.; Rovere-Querini, P. Proangiogenic Tie2(+) macrophages infiltrate human and murine endometriotic lesions and dictate their growth in a mouse model of the disease. Am. J. Pathol. 2011, 179, 2651-2659. [CrossRef]

92. Zuo, Y.; Perkins, N.M.; Tracey, D.J.; Geczy, C.L. Inflammation and hyperalgesia induced by nerve injury in the rat: A key role of mast cells. Pain 2003, 105, 467-479. [CrossRef]

93. Tran, L.V.; Tokushige, N.; Berbic, M.; Markham, R.; Fraser, I.S. Macrophages and nerve fibres in peritoneal endometriosis. Hum. Reprod. 2009, 24, 835-841. [CrossRef]

94. Aich, A.; Afrin, L.B.; Gupta, K. Mast cell-mediated mechanisms of nociception. Int. J. Mol. Sci. 2015, 130, 395-412. [CrossRef]

95. Binda, M.M.; Donnez, J.; Dolmans, M.M. Targeting mast cells: A new way to treat endometriosis. Expert Opin. Ther. Targets 2017, 21, 67-75. [CrossRef]

96. Forster, R.; Sarginson, A.; Velichkova, A.; Hogg, C.; Dorning, A.; Horne, A.W.; Saunders, P.T.; Greaves, E. Macrophage-derived insulin-like growth factor-1 is a key neurotrophic and nerve-sensitizing factor in pain associated with endometriosis. FASEB J. 2019, 33, 11210-11222. [CrossRef]

97. Ji, R.R.; Chamessian, A.; Zhang, Y.Q. Pain regulation by non-neuronal cells and inflammation. Science 2016, 354, 572-577. [CrossRef]

98. Vardeh, D.; Wang, D.; Costigan, M.; Lazarus, M.; Saper, C.B.; Woolf, C.J.; Fitzgerald, G.A.; Samad, T.A. COX2 in CNS neural cells mediates mechanical inflammatory pain hypersensitivity in mice. J. Clin. Investig. 2009, 119, 287-294. [CrossRef]

99. Greaves, E.; Horne, A.W.; Jerina, H.; Mikolajczak, M.; Hilferty, L.; Mitchell, R.; Fleetwood-Walker, S.M.; Saunders, P.T. EP2 receptor antagonism reduces peripheral and central hyperalgesia in a preclinical mouse model of endometriosis. Sci. Rep. 2017, 7, 44169. [CrossRef]

100. Acien, P.; Quereda, F.; Campos, A.; Gomez-Torres, M.J.; Velasco, I.; Gutierrez, M. Use of intraperitoneal interferon alpha-2b therapy after conservative surgery for endometriosis and postoperative medical treatment with depot gonadotropin-releasing hormone analog: A randomized clinical trial. Fertil. Steril. 2002, 78, 705-711. [CrossRef]

101. Acien, P.; Quereda, F.J.; Gomez-Torres, M.J.; Bermejo, R.; Gutierrez, M. GnRH analogues, transvaginal ultrasound-guided drainage and intracystic injection of recombinant interleukin-2 in the treatment of endometriosis. Gynecol. Obstet. Investig. 2003, 55, 96-104. [CrossRef] [PubMed]

102. Haber, E.; Danenberg, H.D.; Koroukhov, N.; Ron-El, R.; Golomb, G.; Schachter, M. Peritoneal macrophage depletion by liposomal bisphosphonate attenuates endometriosis in the rat model. Hum. Reprod. 2009, 24, 398-407. [CrossRef] [PubMed]

103. Ihara, T.; Uchiide, I.; Sugamata, M. Light and electron microscopic evaluation of antileukotriene therapy for experimental rat endometriosis. Fertil. Steril. 2004, 81, 819-823. [CrossRef] [PubMed]

104. Guney, M.; Oral, B.; Karahan, N.; Mungan, T. Regression of endometrial explants in a rat model of endometriosis treated with melatonin. Fertil. Steril. 2008, 89, 934-942. [CrossRef] [PubMed]

105. Yildirim, G.; Attar, R.; Ozkan, F.; Kumbak, B.; Ficicioglu, C.; Yesildaglar, N. The effects of letrozole and melatonin on surgically induced endometriosis in a rat model: A preliminary study. Fertil. Steril. 2010, 93, 1787-1792. [CrossRef]

106. Schwertner, A.; Conceição Dos Santos, C.C.; Costa, G.D.; Deitos, A.; de Souza, A.; de Souza, I.C.; Torres, I.L.; da Cunha Filho, J.S.; Caumo, W. Efficacy of melatonin in the treatment of endometriosis: A phase I.I.; randomized, double-blind, placebo-controlled trial. Pain 2013, 154, 874-881. [CrossRef] 
107. Iuvone, T.; Affaitai, G.; De Filippis, D.; Lopopolo, M.; Grassia, G.; Lapenna, D.; Negro, L.; Costantini, R.; Vaia, M.; Cipollone, F.; et al. Ultramicronized palmitoyilethanolamide reduces viscervisceral hyperalgesia in a rat model of endometriosis plus ureteral calculosis: Role of mast cells. Pain 2016, 157, 80-91. [CrossRef]

108. Indraccolo, U.; Indraccolo, S.R.; Mignini, F. Micronized palmitoylethanolamide/trans-polydatin treatment of endometriosisrelated pain: A meta-analysis. Ann. Ist. Super. Sanita. 2017, 53, 125-134.

109. Hart, D.A. Curbing inflammation in multiple sclerosis and endometriosis: Should mast cells be targeted? Int. J. Inflamm. 2015, 2015, 452095. [CrossRef]

110. Cuzzocrea, S.; Tan, D.X.; Costantino, G.; Mazzon, E.; Caputi, A.P.; Reiter, R.J. The protective role of endogenous melatonin in carrageenan-induced pleurisy in the rat. FASEB J. 1999, 13, 1930-1938. [CrossRef]

111. Blurton-Jones, M.; Kuan, P.N.; Tuszynski, M.H. Anatomical evidence for transsynaptic influences of estrogen on brain-derived neurotrophic factor expression. J. Comp. Neurol. 2004, 468, 347-360. [CrossRef]

112. Allen, A.L.; McCarson, K.E. Estrogen increases nociception-evoked brain-derived neurotrophic factor gene expression in the female rat. Neuroendocrinology 2005, 81, 193-199. [CrossRef]

113. Garcia-Fernandez, J.; García-Velasco, J.A. Endometriosis and Reproduction: What We Have Learned. Yale J. Biol. Med. 2020, 93, 571-577.

114. Raffi, F.; Metwally, M.; Amer, S. The impact of excision of ovarian endometrioma on ovarian reserve: A systematic review and meta-analysis. J. Clin. Endocrinol. Metab. 2012, 97, 3146-3154. [CrossRef]

115. Muzii, L.; Di Tucci, C.; Di Feliciantonio, M.; Galati, G.; Di Donato, V.; Musella, A.; Palaia, I.; Panici, P.B. Antimüllerian hormone is reduced in the presence of ovarian endometriomas: A systematic review and meta-analysis. Fertil. Steril. 2018, 110, 932-940. [CrossRef]

116. Kitajima, M.; Defrère, S.; Dolmans, M.M.; Colette, S.; Squifflet, J.; Van Langendonckt, A.; Donnez, J. Endometriomas as a possible cause of reduced ovarian reserve in women with endometriosis. Fertil. Steril. 2011, 96, 685-691. [CrossRef]

117. Kitajima, M.; Dolmans, M.M.; Donnez, O.; Masuzaki, H.; Soares, M.; Donnez, J. Enhanced follicular recruitment and atresia in cortex derived from ovaries with endometriomas. Fertil. Steril. 2014, 101, 1031-1037. [CrossRef]

118. Matsuzaki, S.; Pankhurst, M.W. Hyperactivation of dormant primordial follicles in ovarian endometrioma patients. Reproduction 2020, 160, R145-R153. [CrossRef]

119. Koundouros, N.; Poulogiannis, G. Phosphoinositide 3-Kinase/Akt Signaling and Redox Metabolism in Cancer. Front. Oncol. 2018, 8, 160. [CrossRef]

120. Cacciottola, L.; Courtoy, G.E.; Nguyen, T.Y.T.; Hossay, C.; Donnez, J.; Dolmans, M.M. Adipose tissue-derived stem cells protect the primordial follicle pool from both direct follicle death and abnormal activation after ovarian tissue transplantation. J. Assist. Reprod. Genet. 2021, 38, 151-161. [CrossRef]

121. Matsuzaki, S.; Schubert, B. Oxidative stress status in normal ovarian cortex surrounding ovarian endometriosis. Fertil. Steril. 2010, 93, 2431-2432. [CrossRef]

122. Yang, H.; Xie, Y.; Yang, D.; Ren, D. Oxidative stress-induced apoptosis in granulosa cells involves JN.K.; p53 and Puma. Oncotarget 2017, 8, 25310-25322. [CrossRef]

123. Sanchez, A.M.; Papaleo, E.; Corti, L.; Santambrogio, P.; Levi, S.; Viganò, P.; Candiani, M.; Panina-Bordignon, P. Iron availability is increased in individual human ovarian follicles in close proximity to an endometrioma compared with distal ones. Hum. Reprod. 2014, 29, 577-583. [CrossRef]

124. Cobo, A.; Giles, J.; Paolelli, S.; Pellicer, A.; Remohí, J.; García-Velasco, J.A. Oocyte vitrification for fertility preservation in women with endometriosis: An observational study. Fertil. Steril. 2020, 113, 836-844. [CrossRef]

125. Cacciottola, L.; Donnez, J.; Dolmans, M.M. Oxidative stress, mitochondria, and infertility: Is the relationship fully established? Fertil. Steril. 2021, in press. [CrossRef]

126. Mansour, G.; Sharma, R.K.; Agarwal, A.; Falcone, T. Endometriosis-induced alterations in mouse metaphase II oocyte microtubules and chromosomal alignment: A possible cause of infertility. Fertil. Steril. 2010, 94, 1894-1899. [CrossRef] [PubMed]

127. Xu, B.; Guo, N.; Zhang, X.M.; Shi, W.; Tong, X.H.; Iqbal, F.; Liu, Y.S. Oocyte quality is decreased in women with minimal or mild endometriosis. Sci. Rep. 2015, 5, 10779. [CrossRef]

128. Ferrero, H.; Corachán, A.; Aguilar, A.; Quiñonero, A.; Carbajo-García, M.C.; Alamá, P.; Tejera, A.; Taboas, E.; Muñoz, E.; Pellicer, A.; et al. Single-cell RNA sequencing of oocytes from ovarian endometriosis patients reveals a differential transcriptomic profile associated with lower quality. Hum. Reprod. 2019, 34, 1302-1312. [CrossRef]

129. Tomassetti, C.; Meuleman, C.; Pexsters, A.; Mihalyi, A.; Kyama, C.; Simsa, P.; D’Hooghe, T.M. Endometriosis, recurrent miscarriage and implantation failure: Is there an immunological link? Reprod. Biomed. Online 2006, 13, 58-64. [CrossRef]

130. Campos Petean, C.; Ferriani, R.A.; dos Reis, R.M.; de Moura, M.D.; Jordão, A.A., Jr.; Navarro, P.A. Lipid peroxidation and vitamin $\mathrm{E}$ in serum and follicular fluid of infertile women with peritoneal endometriosis submitted to controlled ovarian hyperstimulation: A pilot study. Fertil. Steril. 2008, 90, 2080-2085. [CrossRef]

131. Prieto, L.; Quesada, J.F.; Cambero, O.; Pacheco, A.; Pellicer, A.; Codoceo, R.; Garcia-Velasco, J.A. Analysis of follicular fluid and serum markers of oxidative stress in women with infertility related to endometriosis. Fertil. Steril. 2012, 98, 126-130. [CrossRef]

132. Kishi, I.; Ohishi, M.; Akiba, Y.; Asada, H.; Konishi, Y.; Nakano, M.; Kamei, K.; Yoshimura, Y.; Maruyama, T. Thioredoxin, an antioxidant redox protein, in ovarian follicles of women undergoing in vitro fertilization. Endocr. J. 2016, 63, 9-20. [CrossRef] [PubMed] 
133. Nishihara, T.; Matsumoto, K.; Hosoi, Y.; Morimoto, Y. Evaluation of antioxidant status and oxidative stress markers in follicular fluid for human in vitro fertilization outcome. Reprod. Med. Biol. 2018, 17, 481-486. [CrossRef] [PubMed]

134. Creus, M.; Fábregues, F.; Carmona, F.; del Pino, M.; Manau, D.; Balasch, J. Combined laparoscopic surgery and pentoxifylline therapy for treatment of endometriosis-associated infertility: A preliminary trial. Hum. Reprod. 2008, 23, 1910-1916. [CrossRef] [PubMed]

135. Mier-Cabrera, J.; Genera-García, M.; De la Jara-Díaz, J.; Perichart-Perera, O.; Vadillo-Ortega, F.; Hernández-Guerrero, C. Effect of vitamins $C$ and $E$ supplementation on peripheral oxidative stress markers and pregnancy rate in women with endometriosis. Int. J. Gynaecol. Obstet. 2008, 100, 252-256. [CrossRef]

136. Lu, X.; Wu, Z.; Wang, M.; Cheng, W. Effects of vitamin C on the outcome of in vitro fertilization-embryo transfer in endometriosis: A randomized controlled study. J. Int. Med. Res. 2018, 46, 4624-4633. [CrossRef] 